\title{
İş Kazalarının Lojistik Regresyon Yöntemi İle İncelenmesi: Bayburt İli Örneği
}

DOI: 10.26466/opus.684909

\author{
* \\ Mehmet Bulut* - Hakan Eygü ** \\ * Dr. Öğr. Üyesi, Bayburt Üniversitesi, İ.̇.B.F, Maliye Bölümü, Bayburt, Türkiye \\ E-Posta: mehmetbulut@bayburt.edu.tr \\ ORCID: 0000-0003-0157-4906 \\ ** Doç. Dr., Atatürk Üniversitesi, İ.̇̇.B.F., Ekonometri Bölümü, Erzurum, Türkiye \\ E-Posta: hakaneygu@atauni.edu.tr \\ ORCID: $\underline{0000-0002-4104-2368}$
}

\section{Öz}

Çalışanların sağlığı ve güvenliği, öncelikle beden ve ruh bütünlüğünün korunması yükümlülü̈̆̈̈̈nü ortaya çıkarmaktadır. Nitekim hukuk, kişinin beden ve ruh bütünlüğ̈̈̈ üzerindeki hakkın korunması için zarar vermeme yükümlülü̆ğ̈̈ü hem çalışana hem de işverene yüklemiştir. Bu doğrultuda iş kazalarının ortaya çıkmasına yönelik önlemlerin alınması oldukça önemlidir. İş kazaları, Türkiye'nin çözüm bulmaya çalıştı̆̆ı ancak sonuca ulaşma noktasında başarılı olunamayan sorunlardan birisidir. Bunun en önemli sebeplerinden birisi ise iş sağhlğg ve güvenliği kültürünün yerleşmemesidir. İş kazalarn ile ilgili gerek sektörel gerekse de bölgesel bazda akademik çalışmaların yapılması önem arz etmektedir. Türkiye'de iş kazaları konusunda sektörel bazda bir çok akademik çalışma yapılmasına karşın bölgesel veya il bazında yapılan çalışmalar çok azdır. Bu doğrultuda çalışma ile yerli literatürdeki boşluğun doldurulmasına katkı sağlamak istenmektedir. Kullanılan teknik ile bu alanda yapılan çalı̧̧malara farklı bir boyut kazandıran özgün bir çalışma olduğu söylenebilir. Çalışmamızda Bayburt ilinde 2016-2019 yilları arasında meydana gelen iş kazalarının Binary lojistik regresyon yöntemi ile incelenmesi amaçlanmıştır. Çalışma sonucunda bağımlı değişkenimiz olan kaza sonucu (ölümlü ve yaralanmalı) ile bağımsız değişkenler arasında iş görememe durumu açısından istatistiksel olarak anlamlı ilişki bulunmuştur.

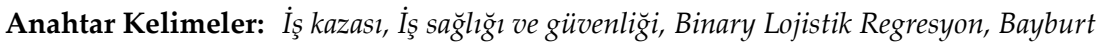




\title{
Investigation of Work Accidents by Logistic Regression Method: The Bayburt Case
}

\begin{abstract}
The health and safety of the employees raise the obligation to protect the integrity of the body and soul. Indeed, the law imposes the obligation not to harm both the employee and the employer on the protection of the right of the person on the integrity of the body and soul. In this direction, it is very important to take measures for the emergence of work accidents. Work accidents, Turkey is trying to find the solution, but it is one of the issues that can not be successful in achieving points. One of the most important reasons for this is that the culture of occupational health and safety is not settled. It is also important to carry out academic studies on work accidents both on a sectoral and regional basis. There are many academic studies on a sectoral basis about work accidents in Turkey. However, studies conducted on a regional or provincial basis are very few. In our study, it was tried to analyze the work accidents occurring in Bayburt Province and it is a pioneer for the studies to be carried out for other provinces. In our study, the work accidents that occurred in Bayburt between 2016-2019 were analyzed by Binary logistics regression method. As a result of the study, a statistically significant relation was found between the accident result (fatal and injured), which is our dependent variable, and independent variables in terms of inability to work.
\end{abstract}

Keywords: Work accident, Occupational health and safety, Binary logistic regression, Bayburt 


\section{Giriş}

İş kazaları, ülkemizde her geçen gün daha çok üzerinde durulan ve en aza indirilmesi için gerekli önlemlerin alınmaya çalışıldığı bir olgu olarak karşımıza çıkmaktadır. Sosyal güvenlik reformu olarak adlandırılan ve 01/10/2008 yılında yürürlüğe giren 5510 sayılı Sosyal Sigortalar ve Genel Sağlık Sigortası Kanunu'ndan önce iş kazaları sigorta kolu sadece hizmet akdine tabi olarak çalışanlar için geçerli iken bu tarihten sonra kapsam genişletilmiş ve kendi nam ve hesabına çalışanlar ile bazı şirket ortakları da kapsama alınmıştır. 5510 sayılı Kanun'da iş kazalarının ortadan kaldırılması ve gerekli önlemlerin alınmasına yönelik olarak doğrudan hükümler yer almamakla beraber Sosyal Güvenlik Kurumu (SGK) tarafından sigortalı veya hak sahiplerine sağlanan yardımların iş kazasının meydana gelmesinde kasıt veya kusuru olan işveren, sigortalı veya üçüncü kişilere rücu edilmesi uygulaması yegâne önlem (ve yaptırım) olarak karşımıza çıkmaktadır.

6331 sayılı İş Sağlığı ve Güvenliği Kanunu'nun yürürlüğe girmesiyle birlikte iş kazalarını önlenmesine yönelik yeni yaptırımlar hayata geçirilmiştir. İş kazası açısından riskli işyerlerinde belli şartlarla işin durdurulması, idari para cezası düzenlemeleri ve ihalelerden yasaklanma uygulamaları ile iş kazalarının önlenmesi için bazı yeni yaptırımlar yürürlüğe girmiştir. Bunun yanı sıra sadece yaptırımlarla iş kazalarının azaltılmasının mümkün olmayabileceği yaklaşımıyla işyerlerine yönelik bazı teşvik uygulamaları da uygulanmaya başlanmıştır. Söz konusu teşvik uygulamaları sadece 6331 sayılı Kanun' da değil torba kanunlarla bazı kanunlarda yapılan değişikliklerle yürürlüğe konulmuştur.

İş kazaları ile mücadele sadece mevzuatsal düzenlemeler ile mümkün değildir. Burada öncelikle gerek çalışan gerekse de işveren açısından iş sağlığı ve güvenliği kültürünün yerleştirilmesi çok önemlidir. Bunun yanı sıra, yapılacak akademik çalışmaların çeşitlendirilmesi ve hem sektörel hem de bölgesel ve il bazında analizlerin yapılması gerekmektedir. Bu noktada Türkiye'de bölgesel ve il bazında iş kazalarına yönelik akademik çalışmaların azlığ dikkat çekmektedir. Bunun en önemli sebebi ise resmi istatistiksel verilerin paylaşımında ortaya çıkan yetersizliklerdir.

Çalışmamızda öncelikle Türk hukuk sisteminde iş kazası kavramının ne şekilde ele alındığına genel olarak değinilecek, ardından Sosyal Güvenlik Ku- 
rumu'nun iş kazalarına yönelik istatistikleri ile ilgili bazı rakamlar paylaşılacaktır. Son olarak ise Sosyal Güvenlik Kurumu Bayburt Sosyal Güvenlik İ Müdürlüğü'nden temin edilen 2016-2019 yılları arasında meydana gelen iş kazalarına ilişkin veriler binary lojistik regresyon analizi ile incelenmiştir.

\section{Türk Hukuk Sisteminde Genel Olarak İş Kazası Kavramı}

İş kazası kavramı genel olarak, işyerinde meydana gelen ve işçiyi bedensel veya ruhsal yönden etkileyen olay olarak tanımlanabilir (TDK, 2019). Ancak Türk hukuk sisteminde iş kazası kavramı daha geniş şekilde ele alınmıştır. İş kazası kavramına ve iş kazası sayılan hallere 5510 sayılı Sosyal Sigortalar ve Genel Sağlık Sigortası Kanunu'nda1 ve 6331 sayılı İş Sağlığı ve Güvenliği Kanunu'nda2 yer verilmiştir. Bunların yanı sıra Sosyal Güvenlik Kurumu tarafından çıkartılan 2016/21 sayılı Genelge'de de iş kazası kavramına ilişkin ayrintılı açklamalarda bulunulmuştur.

5510 sayılı Kanun'un 13 üncü maddesinde iş kazası kavramı açıklanırken bir tanım yapılmaktan öte iş kazası sayılan haller tahdidi olarak sayılmış ve bu hallerden en az birine girip sigortalıyı hemen veya sonradan bedenen ya da ruhen engelli hâle getiren olay iş kazası olarak tanımlanmıştır. Söz konusu maddede iş kazası sayılan haller ise aşağıdaki şekilde sayılmıştır:

a) Sigortalının işyerinde bulunduğu sırada,

b) İşveren tarafindan yürütülmekte olan iş nedeniyle sigortal kendi adına ve hesabına bağımsız çalışıyorsa yürütmekte olduğu iş nedeniyle,

c) Bir işverene bağh olarak çalışan sigortalının, görevli olarak işyeri dışında başka bir yere gönderilmesi nedeniyle asıl işini yapmaksızin geçen zamanlarda,

d) 5510 sayıl Kanunun 4 üncü maddesinin birinci fikrasınm (a) bendi kapsamındaki emziren kadın sigortalının, iş mevzuatı gereğince çocuğuna süt vermek için ayrilan zamanlarda,

e) Sigortalılarm, işverence sağlanan bir taşıtla işin yapıldı̆̆ı yere gidiş̧ gelişi sırasinda meydana gelen olaylar.

6331 sayılı Kanun'un 3 üncü maddesinde ise iş kazası kavramı; işyerinde veya işin yürütümü nedeniyle meydana gelen, ölüme sebebiyet veren veya

${ }^{1}$ Yayımlandığı Resmî Gazete, Tarih: 16/6/2006, Sayı: 26200.
2 Yayımlandığı Resmî Gazete, Tarih: 30/6/2012, Sayı: 28339. 
vücut bütünlügünü ruhen ya da bedenen engelli hâle getiren olay olarak tanımlanmıştır. Bu yönüyle her iki kanundaki iş kazası tanımının birbiri ile paralel olarak düzenlendiğini, ancak 6331 sayılı Kanun'daki tanımın bazı eksiklikleri olduğunu söyleyebiliriz. Nitekim 5510 sayılı Kanun'da bir olayın iş kazası sayılabilmesi için olayın objesinin yani kazayı geçiren kişinin niteliği ön plana çıkartılmıştır. Buna göre bir olayın iş kazası sayılabilmesi için kazayı geçiren kişinin sigortalı sayılması şarttır. 5510 sayılı Kanun'a göre söz konusu sigortalılığın 4/a (başka bir deyişle hizmet akdine tabi olarak çalışma) veya 4/b (başka bir deyişle kendi nam ve hesabına çalışma) kapsamında olması gerekmektedir. Ayrıca iş kazası sigorta kolunun uygulanması açısından sigortalının belli bir süre sigortalı olması ya da prim ödeme koşulu aranmamaktadır (Sümer, 2019, s. 91). Bununla birlikte iş kazası kavramı için ceza hukuku bağlamında net ve kesin bir iş kazası tanımı yapılması fiil ceza hukukunda fiil esas alındığı için zorunlu değildir (Özkan, 2016, s.562). Uluslararası Çalışma Örgütü (ILO) ise iş kazalarını, işyerinde veya çalışma sırasında meydana gelen, ölüm, kişisel yaralanma veya hastalıkla sonuçlanabilen kazalar olarak tanımlamaktadır. (ILO, 2018, s.2).

Sosyal Güvenlik Kurumu tarafından çıkartılan 2016/21 sayılı Genelge'ye göre ise bir olayın iş kazası sayılabilmesi için; kazayı geçiren kişinin sigortalı olması, kaza sonucu bedence veya ruhça engelli hale gelmesi, kaza ile sonuç arasında uygun bir illiyet bağının bulunması ve olayın 5510 sayılı Kanun'un 13 üncü maddesinde sayılan hallerden birinde meydana gelmesi gerekmektedir (SGK, 2016, s. 1). Dolayısıyla meydana gelen olayın iş kazası sayılabilmesi için en önemli nokta, olayın 5510 sayılı Kanun'da sayılan beş halden birine dahil olmasıdır. Buna göre, sigortalının işyerinde bulunduğu sırada meydana gelen olayların yapılan işle ilgili olup olmadığına bakılmaksızın iş kazası sayılması gerekmektedir (SGK, 2016, s. 2). Başka bir deyişle, yapılan iş ile ilgili olsun veya olmasın, mesai saatleri içerisinde gerçekleşsin veya gerçekleşmesin, sigortalının kusuru/kastı olsun veya olmasın işyeri sayılan yerlerde (işyerinin aslı, işyerine bağlantılı yerler, işyeri eklentileri ve araçlarda) meydana gelen kazaların tümü iş kazası olarak nitelendirilebilecektir.

Bununla birlikte sigortalının işyeri dışında başına gelen olayların da iş kazası sayılması söz konusu olabilecektir. Nitekim "işveren tarafından yürütülmekte olan iş" ifadesiyle, işyerinde veya işyeri dışında meydana gelen kazanın işverenin görevlendirmesi veya işin niteliği gereği yapıldığı sırada karşılaşabileceği kaza riskine karşı sigortalı teminat altına alınmaktadır (SGK, 
2016, s.3). Ayrıca sigortalının işveren tarafından görev ile başka bir yere gönderilmesi nedeniyle asıl işini yapmaksızın geçen zamanlarda meydana gelen kazaların da iş kazası sayılması gerekmektedir. Burada göz önünde bulundurulması gereken husus, meydana gelen kazanın işverenin sigortalıya vermiş olduğu görevle ilgili olup olmadığı, görevin yapılması için geçen süre içinde meydana gelip gelmediğinin tespitine bağlı bulunmaktadır (SGK, 2016, s.3).

İş kazası sayılan bir diğer hale göre ise, sigortalıların işverence sağlanan bir taşıtla işin yapıldığı yere gidiş-gelişi sırasında meydana gelen kazalar iş kazası sayılacaktır. Burada önemli olan işverence sağlanan bir taşıtın bulunması ve sigortalıların işin yapıldığı yere getirilip götürülmeleri sırasında meydana gelen olayın, yine işverenin kiraladığı bir minibüs veya işyerine ait servis aracı ile sigortalıların evlerinden işyerine, işin bitiminde de işyerlerinden evlerine getirilip götürülmeleri sırasında meydana gelen trafik kazasının, sigortalının servis aracından inerken düşerek yaralanması veya araç içinde herhangi bir nedenle meydana gelen olayın, iş kazası sayılması gerekmektedir (SGK, 2016, s.4).

İş kazalarının, ilk müdahale, ambulans ve tedavi masrafları, geçici veya sürekli iş göremezlik ve ölüm ödemeleri, işçiye veya yakınlarına ödenen maddi ve manevi tazminatlar, sigortaya ödenen tazminatlar gibi doğrudan maliyetlerinin yanı sıra bazı dolaylı maliyetleri bulunmaktadır (Bekar, Otuç ve Bekar, 2017, s. 480). Gerek çalışan sağlığı ve hayatının korunması gerekse de ortaya çıkacak doğrudan ve dolaylı maliyetlerin ülke ekonomisi üzerindeki etkilerini ortadan kaldırmak açısından iş kazaları ile mücadele ve gerekli önlemlerin alınması elzemdir. İş kazalarında en önemli husus kazayı ortaya çıkaran durumların tespiti ve önlenmesi olup, iş kazalarını önlemek için çeşitli çalışmalar yapılmış ve farklı teknikler ortaya konulmuştur (Polat ve Polat, 2017, s. 25). İş kazalarının ortaya çıkış nedenlerini araştıran çalışmalar iş kazalarının çok çeşitli nedenlerinin bulunduğunu ortaya koymakta olup iş kazalarının nedenleri ve çeşitliliği; ülkenin sanayileşmesine, işletme türlerine, istatistik ve araştırmalarının düzeylerine, denetim hizmetlerine, çalışanların niteliklerine ve iş güvenliği bilincine göre değişmektedir (Kaplan ve Çallı Kaplan, 2019, s. 77). Ayrıca çalışma koşullarının ve alınan/alınmayan önlemlerin iş kazaları üzerinde direkt etkili olduğu yönünde birçok akademik çalişma bulunmaktadır (Durgun, Serin ve Şahin, 2015, s.548; Davas, Türk ve Yüksel, 2016, s.74) 
Bir olayın iş kazası sayılıp sayılmaması sigortalı açısından büyük bir öneme sahiptir. İş kazaları sonucunda mağduriyete uğrayan işçiye bu mağduriyetin giderilmesi için bazı yardımların yapılması gerekmekte olup bu yardımların sağlık yardımları ve parasal yardımlar olarak sınıflandırılması mümkündür (Oğuz, 2018, s. 320). İş kazası sonrasında sigortalıya sağlanacak haklar sıradan olaylar sonrasında sigortalıya sağlanan haklara nazaran bazı avantajlar içermektedir. Örneğin, sigortalının hastalanması neticesinde verilen geçici iş göremezlik ödeneğinde, iş göremezliğin başladığg tarihten önceki bir yıl içinde en az doksan gün kısa vadeli sigorta kolları primi ödenmiş olmalıdır ve bu ödeneğin ödenmesine istirahatin üçüncü günü başlanmaktadır. Buna karşın iş kazası sonucu ödenecek geçici iş göremezlik ödeneğinde herhangi bir prim ödeme süresi şartı olmadığı gibi ödeneğin ödenmesine istirahatin birinci günü başlanmaktadır.

Buna benzer şekilde, sigortalının sıradan bir olay neticesinde sürekli iş göremez hale gelmesi ile iş kazası sonucu sürekli iş göremez hale gelmesinin de sonuçları açısından bazı farkları vardır. Nitekim sıradan bir olay neticesinde sürekli iş göremez hale gelinmesi halinde malullük aylığı bağlanabilmekte, ancak bunun için belirli süre prim ödenmiş olma şartı bulunmaktadır. Ayrıca malullük aylığı ödenen kişi sigortalı olarak çalışmaya başlaması halinde malullük aylığı kesilmektedir. Buna karşın iş kazası sonucunda sürekli iş göremez hale gelme durumunda sürekli iş göremezlik geliri bağlanmakta olup burada herhangi bir prim ödeme şartı olmadığı gibi çalışılması halinde sürekli iş göremezlik geliri kesilmemektedir. Belirtilen avantajlara benzer bir durum ölüm halinde de söz konusudur. Nitekim iş kazası dışında bir sebeple ölüm halinde hak sahiplerine ölüm aylığı bağlanabilmesi için belirli süre prim ödeme şartı bulunurken, iş kazası sonucu ölümlerde ölüm geliri bağlanabilmesi için herhangi bir prim ödeme süresi şartı bulunmamaktadır. Kısacası bir olayın iş kazası sayılıp sayılmaması sağlanan haklar açısından önem arz etmekte olup durumun ve sorumlulukların tespiti oldukça önemlidir.

Türkiye'de iş kazaları ve ölüm oranları için 2001-2005 dönemini kapsayan 5 yıllık iş kazası istatistikleri incelenmiş iş güvenliği ve işçi sağlı̆ı gibi konularda öncelikle çalışılması gerekli illerin tespiti amaçlanmıştır (Ünal ve Gök, 2009, s. 292). Eser (2015) iş kazalarının sonuçlarını çeşitli değişkenler kullanarak regresyon analizi incelemiştir. Çalışma sonucu en çok iş kazası geçiren çalışanların, üç ay ile bir yıl arasında deneyim sahipleri olduğunu ortaya koymuş ayrıca inşaat, tekstil ve madencilik iş kollarının iş kazası bakımından ilk 
üç sırada olduğunu belirlemiştir. Ulutaş (2016) iş kazaları ve meslek hastalıklarını veri zarflama yöntemi ile araştırmış şehirler için etkinlik değerleri açısından farklılıklar tespit edilmiştir. İş kazaları için sıralı logit model kurulmuş cinsiyet, yaş, kaza türü ve önleyici faaliyet değişkenleri belirlenen anlamlılık seviyesinde istatistiksel olarak anlamlı bulunduğu görülmüş (Eygü, Özçomak ve Orçanlı, 2018, s. 1216), ayrıca inşaat sektörüne ait iş kazası verileri kullanılarak risk programı ile kaza meydana gelme sıklı̆̆ı, etki derecesi için uygun olasılık dağılımları ve parametreleri belirlenerek modellenmesi sağlanmıştır (Erginel ve Toptanc1, 2017, s. 201).

\section{Türkiye'de ve Bayburt İli'nde İş Kazalarının İstatistiksel Görünümü}

Türkiye'de meydana gelen iş kazası sayılarına ve iş kazalarının niteliksel dağılımına ilişkin istatistiksel veriler Sosyal Güvenlik Kurumu tarafından tutulmakta ve paylaşılmaktadır. Bununla birlikte bazı sivil toplum kuruluşları tarafından da iş kazalarına ilişkin istatistiksel paylaşımların olduğu görülmektedir. Buna karşın iş kazaları açısından en önemli ve yetkili kuruluşlardan birisi olan İş Sağllğı ve Güvenliği Genel Müdürlüğü tarafından herhangi bir istatistiksel paylaşımda bulunulmamaktadır. Sosyal Güvenlik Kurumu ise en son 2017 yılına ilişkin iş kazası istatistiklerini resmi internet sitesinden paylaşmıştır. Sosyal Güvenlik Kurumu'na bağlı il müdürlüklerinin resmi internet sitelerinden illerinde meydana gelen iş kazaları ile ilgili herhangi bir istatistiksel veri paylaşımı bulunmamaktadır.

Sosyal Güvenlik Kurumu tarafından yayınlanan 2017 yılına ilişkin istatistik yıllığında yer alan verilere göre iş kazaları rakamlarını aşağıdaki şekilde özetleyebiliriz (SGK, 2017):

- Toplam İş Kazası Sayısı: 359.653

- İş Kazası Geçiren Erkek Sigortalı Sayısı: 300.770

- $\quad$ İş Kazası Geçiren Kadın Sigortalı Sayısı: 58.883

- Kaza Günü Çalışır Durumda Olunan İş Kazası Sayısı: 187.986

- $\quad$ İş Göremezlik Oluşan İş Kazası Sayısı: 171.667

- $\quad$ Toplam Geçici İş Göremezlik Süresi (Gün): 3.996 .873

- İş Kazası Sonucu Ölen Sigortalı Sayısı: 1.633

- 2017 Yılı İçinde Sürekli İş Göremezlik Geliri Bağlanan Kişi Sayısı: 85

- $\quad 2017$ Yılı İçinde Ölüm Geliri Bağlanan Hak Sahibi Sayısı: 6.498

- En Fazla İş Kazası Meydana Gelen Sektörler: 
○ $\quad$ Bina İnşaatı: 34.952

- Fabrikasyon Metal Ürünleri İmalatı: 23.627

- Bina Dışı Yapıların İnşaatı: 20.873

○ Gida Ürünlerinin İmalatı: 20.270

- $\quad$ Yiyecek ve İçecek Hizmeti Faaliyeti: 16.824

○ Tekstil Ürünlerinin İmalatı: 16.520

- Ana Metal Sanayi: 15.670

Yine Sosyal Güvenlik Kurumu tarafından yayınlanan 2017 yılına ilişkin istatistik yıllığında yer alan verilere göre Bayburt İli'nde meydana gelen iş kazaları rakamlarını da aşağıdaki şekilde özetleyebiliriz (SGK, 2017):

- Toplam İş Kazası Sayısı: 67

- İş Kazası Geçiren Erkek Sigortalı Sayısı: 61

- İş Kazası Geçiren Kadın Sigortalı Sayısı: 6

- $\quad$ Kaza Günü Çalışır Durumda Olunan İş Kazası Sayısı: 42

- İş Göremezlik Oluşan İş Kazası Sayısı: 25

- Toplam Geçici İş Göremezlik Süresi (Gün): 1.054

- İş Kazası Sonucu Ölen Sigortalı Sayısı: 1

- 2017 Yllı İçinde Sürekli İş Göremezlik Geliri Bağlanan Kişi Sayısı:0

- 2017 Yılı İçinde Ölüm Geliri Bağlanan Hak Sahibi Sayısı: 3

\section{Yöntem}

Çalışma, işletmelerde kullanılan iş kazası bildirim forumlarındaki değişkenler analize dahîl edilerek işletmelerde meydana gelen iş kazalarının incelenmesi bakımından betimsel tarama araştırmasıdır. Betimsel tarama araştırmaları ele alınan bir örneklemde, belirlenen değişkenler bakımından mevcut durumu ortaya koymak üzere gerçekleştirilirler. Çok sayıda denekten veri toplama imkânı sağlayan bu yöntem, onları iyi anlayabilme, gruplayabilme ve aralarındaki ilişkileri saptayabilme olanağı sağlamaktadır.

Uygulama konusu iş kazalarının incelenmesi olduğu için çalışmada Lojistik regresyon yöntemi kullanılması uygun olduğu belirlenmiş (Eygü vd., 2018) olup bu yöntem bağımlı değişkenin niteliğine göre binary, sıralı, multinominal lojistik regresyon olmak üzere üç farklı grupta incelenebilir. Lojistik regresyon yönteminin kullanılmasının nedeni, fonksiyonun matematiksel açıdan çok esnek olması, kullanım kolaylığı ve sonuçların konu açısından an- 
lamlı bir şekilde yorumlanabilmesidir (Alpar, 2011). Ayrıca bağımsız değişkenlerin çok değişkenli normal dağılıma uygun olması ve sahip olduğu bilinen grupların varyans ve kovaryanslarının homojen olması gibi önemli varsayımlara ihtiyaç duymadan kullanılabilmesidir (Akın ve Şentürk, 2012). Çalışmada bağımlı değişkenin iki kategorili verilerden oluşması nedeniyle binary lojistik regresyon analizi kullanılmasının uygun olduğu belirlenmiştir.

\section{Veri Toplama ve Örneklem}

Araştırmanın uygulama yöntemi, ilişkisel tarama modelidir. İlişkisel tarama modelleri, iki veya daha çok değişken arasındaki ilişkilerin incelendiği korelasyonel araştırmalardır. Bu araştırmaların amacı, değişkenlerin birlikte değişimlerinin veya değişkenler arasındaki ilişkilerin belirlenmesidir. Bu kapsamda yapılan çalışmada uygulama yöntemi olarak regresyon modellerinden binary (ikili) lojistik regresyon modeli kullanılmıştır.

Yapılan çalışmada veri seti olarak Bayburt Sosyal Güvenlik İl Müdürlüğ̈̈'nden elde edilen 2016-2019 yılları arasında meydana gelen iş kazası verileri kullanılmıştır. Bu doğrultuda araştırmada bu yıllar arasında meydana gelen 81 iş kazası verisinden yararlanılmıştır.

\section{Lojistik Regresyon Modeli}

Son yıllarda, kategorik veriler için genelleştirilmiş doğrusal modellerin kullanımı, özellikle de sosyal bilimlerdeki uygulamalar için belirgin bir şekilde artmıştır. Bu durum, kategorik verilerin analizi için son yıllarda karmaşık yöntemlerin geliştirilmesinin kapsamını yansıtmaktadır. Aynı zamanda, çoğu şimdi kategorik yanıtlarla sürekli veriler için yöntemler kullanmanın gereksiz ve çoğu zaman uygunsuz olduğunu fark eden bilim adamlarının ve uygulamalı istatistikçilerin artan metodolojik karmaşıklığını göstermektedir (Eygü ve Kılınç, 2019). İkili veriler kategorik verilerin en yaygın şeklidir, bu nedenle ikili veriler için en popüler model lojistik regresyondur. Lojistik regresyon analizi, bir bağımlı değişkene ait değerleri, bağımlı değişken iki değişken olduğunda bir veya daha fazla bağımsız (tahmin edici) değişkenden tahmin etmektedir. Lojistik regresyonu önemli kılan diğer etkenler şunlardır: log oranlarında uygulanan tahmini parametrelere ait katsayıların tahmin edilme kolaylığı, belirli bir konunun sonucu geliştirme olasılığını tahmin etme kabiliyeti ve geniş kullanım alanıdır (Barkus vd., 2006, s. 57-64). 
Araştırmalarda çoğu zaman bağımlı ve bağımsız değişkenlerin tür ve yapıları birbirine benzememektedir. İncelenen değişkenlerin bazıları hassas ölçekle ölçülmekle beraber, bazıları da iki kategorili verilerden oluşmaktadır. İki farklı değer içeren verilere iki kategorili (Binary) veriler denilmektedir. İki kategorili değişkenler literatürde, 0-1 değişkenleri olarak da adlandırılmaktadır. Bağımlı değişkenin iki şıklı kategorik veriler olması durumunda, bağımsız değişkenle bağımlı değişken arasındaki sebep-sonuç ilişkisini incelerken İki Değişkenli (Binary) Lojistik Regresyon Analizi kullanılır (Oktay ve Orçanl, 2014). Bu regresyon modelinin temelinde olasıllk teorisi yer almakta ve bu modelin önemi hem bağımlı hem de bağımsız değişkenler arasındaki ilişkiyi fonksiyonel olarak incelemesidir. Bu doğrultuda lojistik regresyon modeli, olasılık oranının logaritması alınarak, modelin parametrelerini tahmin ederken en yüksek olabilirlik (maximum likelihood) yöntemi kullanılır. Böylece iki değişkenli lojistik regresyon modeli,

$P(Y)=\frac{e^{\beta_{0}+\beta_{1} X}}{1+e^{\beta_{0}+\beta_{1} X}}=\frac{1}{1+e^{-\beta_{0}-\beta_{1} X}}$

şeklinde yazılır. Lojistik regresyon modelindeki katsayılar,

$\ln \left(\frac{P(Y)}{Q(Y)}\right)=\beta_{0}+\beta_{1} X_{1}+\beta_{2} X_{2}+\ldots+\beta_{p} X_{p}$

ve

$\frac{P(Y)}{Q(Y)}=e^{\beta_{0}+\beta_{1} X_{1}+\beta_{2} X_{2}+\ldots+\beta_{p} X_{p}}=e^{\beta_{0}} e^{\beta_{1} X_{1}} e^{\beta_{2} X_{2}} \ldots e^{\beta_{p} X_{p}}$

şeklinde hesaplanır. Burada;

$\mathrm{Q}(\mathrm{Y})=1-\mathrm{P}(\mathrm{Y})$ şeklinde hesaplanır. Olasılık oranının $\mathrm{OR}=\mathrm{P}(\mathrm{Y}) / \mathrm{Q}(\mathrm{Y})$ şeklinde hesaplandığı belirtilirse, her bir parametrenin $e^{\beta_{p}}$ değerleri olasılık oranları olarak ele alınırlar. Böylece $e^{\beta_{p}}, \mathrm{Y}$ değişkeninin Xp değişkeninin etkisi ile kaç kat daha fazla ya da yüzde kaç daha fazla gözlenme olasılığına sahip olduğunu belirtir (Özdamar, 1999).

\section{Bulgular ve Tartışma}

Binary lojistik regresyon analizi yapılarak çalışanların ölümlü ve yaralanmalı iş kazasına maruz kalmasında etkili olan faktörlerin neler olduğu ve etkilerinin büyüklüğü belirlenmeye çalışılmıştır. Demografik değişkenler modele 
bağımsız değişkenler olarak dahil edilmiştir. Bu değişkenlere ilişkin tanımlayıcı istatistik sonuçları Tablo 1'de verilmiştir.

Tablo 1. Logit Modelde Kullanılan Bağımsız Değişkenlere Ait Tanımlayıcı İstatistikler

\begin{tabular}{|c|c|c|c|c|c|}
\hline Değişkenler & Frekans (f) & Yüzde (\%) & Değişkenler & Frekans (f) & Yüzde (\%) \\
\hline Cinsiyet & & & $\begin{array}{l}\text { Sektör } \\
\text { (Ekonomik faaliyet) }\end{array}$ & & \\
\hline Erkek & 75 & 92.6 & Ağır işler & 24 & 29.6 \\
\hline Kadın & 6 & 7.4 & İnşaat & 10 & 12.3 \\
\hline Yaş & & & Tesisat/Mobilya & 2 & 2.5 \\
\hline $20-28$ & 27 & 33.3 & Şoför & 6 & 7.4 \\
\hline $29-37$ & 14 & 17.3 & Diğer & 39 & 48.1 \\
\hline $38-46$ & 22 & 27.2 & Kıdem süresi & & \\
\hline 47 ve üzeri & 18 & 22.2 & 1 yıldan az & 54 & 66.7 \\
\hline Meslek & & & $1-3$ yıl & 17 & 21.0 \\
\hline İşçi & 39 & 48.1 & 4 yıl ve üstü & 10 & 12.3 \\
\hline Şoför & 11 & 13.6 & İş görememe durumu & & \\
\hline \multirow[t]{2}{*}{ Diğer } & 31 & 38.3 & Sürekli & 17 & 21.0 \\
\hline & & & Geçici & 64 & 79.0 \\
\hline
\end{tabular}

Oluşturulan modelin uyum iyiliğini değerlendirmek için çoğu zaman Pearson ki-kare testi, parametrelerin anlamlılığının sınanmasında Omnibus ve Wald istatistikleri, Hosmer-Lemeshow Testi gibi yöntemler kullanılmaktadır. Modelin anlamlı olup olmadığını belirlemek amacıyla Omnibus Testindeki model parametrelerinin Ki-kare ( $\chi 2)$ ve p değerleri Tablo 2'de verilmiştir.

Tablo 2. Model Katsayılarnın Omnibus Testleri

\begin{tabular}{rccll}
\hline & $\chi^{2}$ Değeri & s.d & p-değeri \\
\hline Adım 1 & Blok & 19.885 & 11 & 0.047 \\
\hline & Model & 19.885 & 11 & 0.047 \\
\hline
\end{tabular}

Tablo 2'de elde edilen değerler incelendiğinde $\mathrm{p}<0.05$ olduğundan test istatistiğine göre kestirilen katsayıların anlamlı olduğu söylenebilir.

Modelin anlamlı olup olmadığını belirlemek amacıyla yapılan diğer bir test ise Hosmer-Lemeshow Testi'dir. Bu teste ait Kİ-kare ve $p$ değerleri ise Tablo 3'te verilmiştir.

Tablo 3. Hosmer-Lemeshow Testi

\begin{tabular}{llll}
\hline \multirow{2}{*}{ Adım 1} & $\chi^{2}$ Değeri & s.d & p-değeri \\
\cline { 2 - 4 } & 13.861 & 8 & 0.085 \\
\hline
\end{tabular}

$\mathrm{H} 0=$ Model verileri itibariyle uygundur.

H1= Model verileri itibariyle uygun değildir. 
Tablo 3'de elde edilen veriler incelendiğinde $\mathrm{p}>0.05$ olduğundan $\mathrm{H} 0$ hipotezi kabul edilir yani modelin verilerinin anlamlı olduğu söylenebilir. Bu durum modelde bağımlı değişkenimiz olan iş kazası sonucunun ölümlü ve yaralanmalı olayları gruplara ayırmada yeterli bir model olduğu söylenebilir. Buradan, model uyumunun oldukça iyi olduğu ve parametreler belirleyicilik açısından iyi bir ayrımcılığa sahip olduğu sonucuna varılabilir.

Modelin ne kadar iyi çalışıp çalışmadığını anlamak için uyum iyiliği testi yapılmıştır. Lojistik regresyonda doğrusal regresyonda olduğu gibi bağımlı ve bağımsız değişkenler arasında ilişkiyi ölçen bir $\mathrm{R}^{2}$ değeri bulunmuyor. $\mathrm{Bu}$ nedenle regresyon analizi ve lojistik regresyon analizindeki $R^{2}$ değerlerini karşılaştırmak mümkün olmayıp literatürde lojistik regresyon analizi için birkaç $R^{2}$ değeri verilmektedir (Nagelkerke, 1991). Literatürde genelde McFaden $\mathrm{R}^{2}$, Cox-Snell ve Nagelkerke $\mathrm{R}^{2}$ değerleri kullanıldığı görülmektedir. Tablo 4 'te uyum iyiliği test sonuçları verilmiştir.

\section{Tablo 4. Pseudo $R^{2}$ Değerleri}

\begin{tabular}{llll}
\hline \multirow{2}{*}{ Adım 1} & -2 Log Likelihood & Cox \&S nell & Nagelkerke \\
\cline { 2 - 4 } & 17.650 & 0.218 & 0.587 \\
\hline
\end{tabular}

Tablo 4'te modelin $\mathrm{R}^{2}$ değerleri verilmiş, bu değerlere göre bağımlı değişkenin yüzde kaçının bağımsız değişkenler tarafından açıklandığını göstermektedir. Literatürde $\mathrm{R}^{2}$ değerlerinin $0.20-0.40$ arsında olması modelin açıklanması için uygun olduğu belirtilmektedir. Bu nedenle modelin uygunluğunun değerlendirmesinde elde edilecek olan değerin bu değerler arasında olmasını bekleriz. Sonuç olarak, elde edilen değerler bu değerler arasında olması nedeniyle kurulan modelin uygun olduğunu söyleyebiliriz. (Alpar, 2011, s. 666). Ancak bu değerler kesin sonuçlar vermemektedir. Bu modelde 6 adet bağımsız değişken (cinsiyet, yaş, meslek, sektör, kıdem yılı, iş görememe) bulunmakta ve değişkenlerin olasılık değerlerine bakılmalıdır. $\mathrm{Bu}$ olasılık değerleri, parametrelerin anlamlı olup olmadığını belirlemek için Wald testine ait değerlerdir. Ancak lojistik regresyon analizinde söz konusu elde edilen katsayıların yorumlanması için Wald istatistiğinin e $\beta$ şeklinde hesaplanarak odds oranına ulaşılması ve referans kategorilerinin belirlenmesi gerekmektedir. Yani yorumlama belirlenen referans kategoriye göre yapıl- 
malıdır. Odds oranının yorumlanmasında; odds değerinin birden büyük olması durumunda sonuçta meydana gelen artma oranından, odds değerinin birden küçük olması durumunda sonuçta meydana gelen azalma oranından söz edilmektedir (Eygü ve Kılınç, 2019). Çalışmada referans kategorisi ise son kategori olarak belirlenmiş yorumlar buna göre yapılmıştır. Tablo 5 'te lojistik regresyon analiz sonuçları verilmiştir.

Tablo 5. Parametre Tahminleri

\begin{tabular}{lllllll}
\hline \multicolumn{1}{c}{} & $\mathbf{B}$ & $\mathbf{s . h}$ & Wald & $\mathbf{s . d}$ & $\mathbf{p}$ & $\left(\mathrm{e}^{\boldsymbol{\beta}}\right)$ \\
\hline Bağımsız Değişkenler & & & & & \\
\hline [cinsiyet=2] & 16.471 & 11920.7 & 0.000 & 1 & 0.999 & 14233811.01 \\
\hline [yas=1] & -0.808 & 1.364 & 0.351 & 1 & 0.553 & 0.446 \\
\hline [yas=2] & -17.733 & 8861.307 & 0.001 & 1 & 0.998 & 0.001 \\
\hline [yas=3] & -18.089 & 7004.330 & 0.001 & 1 & 0.998 & 0.001 \\
\hline [meslek=1] & 2.110 & 2.188 & 0.930 & 1 & 0.335 & 8.250 \\
\hline [meslek=2] & 2.316 & 2.435 & 0.905 & 1 & 0.341 & 10.140 \\
\hline [sektör=1] & -19.077 & 6486.593 & 0.001 & 1 & 0.998 & 0.001 \\
\hline [sektör=2] & -0.099 & 1.767 & 0.003 & 1 & 0.955 & 0.906 \\
\hline [kıdem yıll=1] & 17.293 & 10655.531 & 0.001 & 1 & 0.999 & 32363494.54 \\
\hline [kıdem yılı=2] & 16.348 & 10655.531 & 0.001 & 1 & 0.999 & 12856996.65 \\
\hline [isgörememe=1] & 3.0933 & 1.451 & 4.545 & 1 & 0.033 & 22.044 \\
\hline Sabit & -37.573 & 15988.915 & 0.001 & 1 & 0.998 & 0.001 \\
\hline
\end{tabular}

Tablo 5 incelendiğinde bağımsız değişkenler arasında sadece çalışanın iş kazası sonucunda iş görememe durumu değişkeninin anlamlı $(\mathrm{p}<0.05)$ olduğu bulunmuştur. Bu durumda iş görememe durumu değişkeni üzerindeki 1 birimlik değişimin, sürekli iş görememe durumundan geçici iş görememe durumuna eğilim olasılığını 22.044 kat arttırdığını ortaya koymaktadır.

\section{Sonuç}

Yapılan çalışmalar incelendiğinde işletmelerde çalışanların daha güvenli koşullarda ve sürekli olarak çalışmaları için, organizasyonlarda etkin güvenlik kültürünün varlığı gerekli olduğu sonucuna varılmıştır. İşçi sağlığı ve güvenliğine dair kanun, kural, uygulama, önlem vb.nin oluşturulmasında, hayata geçirilmesinde, uygulanmasında, uyulmasında sosyo-kültürel yapı önem taşımaktadır. Nitekim riskin algılanması, tedbirlere uyma, güvenli davranma, psiko-sosyal sağlığın korunması kültürel yapılardan etkilenmektedir. Yapı- 
lan akademik çalışmalarda getirilen iş kazalarını önlemeye yönelik tüm önerilere karşın değişimin bir anda ve hemen olmayacağı açıktır. Düzenleme ve deneyimler, toplumdaki kurallara uyma davranışı alışkanlığı, sosyo-ekonomik gelişmişlik düzeyi, gelir dağılımındaki adalet, iktisadi politik model tercihi gibi makro temelleri de ilgilendirmektedir. Bu temellerle birlikte sağlanacak toplumsal bilinçlenme nihai çözüm olacaktır.

$\mathrm{Bu}$ çalışmanın amacı yerli literatürdeki boşluğun doldurulmasına katkı sağlamaktır. Kullanılan teknik ile bu alanda yapılan çalışmalara farklı bir boyut kazandıran özgün bir çalışma olduğu söylenebilir. Çalışmada uygulama yöntemi olarak regresyon modellerinden binary lojistik regresyon modeli kullanılmıştır. Çünkü bağımlı değişkenimizin iki kategorili verilerden oluşmasından dolayı bu yöntemin uygun olduğu belirlenmiştir. Modelin uygunluk değeri olan Pseudo R2 değerinin yüksek olduğu belirlenmiş ve bu değere göre bağımlı değişken olan kaza sonucunun bağımsız değişkenler tarafından iyi bir şekilde açıklandığı görülmüştür.

Çalışmaya bağımsız değişken olarak kaza sonucu ölümlü ve yaralanmalı olarak alınmış ve bağımsız değişkenler olarak ise çalışanların cinsiyeti, yaşı, mesleği, çalışılan sektör ve kıdem yılı alınmıştır. Bu değişkenler arasında sadece çalışanın iş kazası sonucunda iş görememe durumu değişkeninin anlamlı olduğu söylenebilir. Diğer değişkenler arasında bir ilişki bulunmamış olup bu değişkenler arasında anlamlı ilişkiler olacağı beklenmiştir. Ancak çalışmaya sadece Bayburt ili dahil edilmiş olup bu ilimizin hem nüfusunun hem de işletmelerin azlığı dikkate alındığında buna bağlı olarak 2016-2019 yılları arasında meydana gelen iş kazalarına ilişkin verilerin azlığı nedeniyle ilişki bulunamadığı söylenebilir. Çalışmanın bir sonraki aşamasında verilerin temini için gerekli izinlerin alınması koşuluyla Türkiye geneli için yapılması düşünülmektedir.

\section{Teşekkür}

Bu çalışma Sosyal Güvenlik Kurumu Bayburt Sosyal Güvenlik İl Müdürlüğü'nden alınan verilerle hazırlanmıştır. Bu verileri almamızda kolaylık sağlayan Bayburt Sosyal Güvenlik İl Müdürlüğü'ne teşekkür ederiz. 


\title{
EXTENDED ABSTRACT
}

\section{Investigation of Work Accidents by Logistic Regres- sion Method: The Bayburt Case}

\author{
Mehmet Bulut - Hakan Eygü \\ Bayburt University - Atatürk University
}

Work accidents is a fact that tried to take the necessary measures for the emphasis much more with each passing day and minimized in Turkey. Combating work accidents is not only possible with legislative regulations. At this point, it is very important to establish a culture of occupational health and safety primarily for employees and employers. In addition, it is necessary to diversify the academic studies to be conducted and to analyze both on a sectoral and regional and provincial basis. At this point, it is noteworthy that the lack of regional and province-based academic work against work accidents in Turkey. The most important reason for this is the inability to share official statistical data.

In our study, firstly, how the concept of work accident is handled in the Turkish legal system will be mentioned in general, and then some figures related to the statistics of the Social Security Institution regarding work accidents are shared. Finally, data related to work accidents that occurred between 2016-2019 provided by the Social Security Institution Bayburt Provincial Directorate were analyzed by binary logistic regression analysis.

The study is a descriptive survey study in terms of examining the work accidents occurring in the enterprises by including the variables in the work accident reporting forums in the analysis. Descriptive survey studies are carried out to reveal the current situation in terms of the determined variables in a sample. This method, which provides the opportunity to collect data from a large number of subjects, provides the opportunity to understand, group and identify the relationships between them.

The application method of the research is the relational screening model. Relational screening models are correlational studies examining the relationships between two or more variables. The purpose of these studies is to deter- 
mine the co-variation of the variables or the relationships between the variables. In this study, binary logistic regression model, one of the regression models, was used as the application method. As a data set, the data of work accidents that occurred between 2016-2019 obtained from Bayburt Provincial Directorate of Social Security were used. Accordingly, 81 work accident data that occurred between these years were used in the study.

Since the subject of application is the examination of work accidents, it is determined that the logistic regression method is appropriate in the study and this method can be examined in three different groups as binary, sequential and multinominal logistic regression depending on the nature of the dependent variable. The reason for using the logistic regression method is that the function is very mathematically flexible, ease of use, and the results can be interpreted in a meaningful way. In addition, the fact that independent variables are suitable for multivariate normal distribution and that the variances and covariances of the groups known to be homogeneous can be used without the need for important assumptions. In the study, it was determined that binary logistic regression analysis was appropriate because the dependent variable was composed of two categories of data.

The aim of this study is to contribute to filling the gap in the domestic literature. It can be said that it is an original work that adds a different dimension to the work done in this field with the technique used. In the study, binary logistic regression model, one of the regression models, was used as the application method. Because our dependent variable consists of two categories of data, this method has been determined to be appropriate. The Pseudo R2 value, which is the suitability value of the model, was determined to be high and it was seen that the accident result, which is the dependent variable according to this value, is well explained by the independent variables. In the study, the independent variable was taken as fatal and injured as an accident, and the independent variables were the gender, age, profession, sector and seniority year of the employees. Among these variables, it can be said that the variable of not being able to work as a result of the worker's accident is meaningful. There was no relationship between the other variables and it was expected that there would be significant relationships between these variables. However, only the province of Bayburt was included in the study, and considering the scarcity of the population and businesses of this province, it can be said that there is no relation due to the low number of data related to 
work accidents that occurred between 2016-2019. The next phase of the study, provided government authorizations necessary for the supply of data being considered for overall Turkey.

\section{Kaynakça / References}

Akın, B.H. ve Şentürk, E. (2012). Bireylerin mutluluk düzeylerinin ordinal lojistik regresyon analizi ile incelenmesi. Öneri Dergisi, 10(37), 183-193.

Alpar, R. (2011). Uygulamal çok değişkenli istatistiksel yöntemler. 3. Baskı, Ankara: Detay Yayıncllk.

Ayten, E. (2015). Güncel iş kazaları verilerinin istatistiki analizi. Çukurova Üniversitesi Mühendislik-Mimarlk Fakültesi Dergisi, 30(2), 227-242.

Barkus, E., Foster, J. ve Yavorsky, C. (2006). Understanding and Using Advanced Statistics. 1. Addition, London:Sage Publications,

Bekar, I., Otuç, D. ve Bekar, E. (2017). İş kazası ve meslek hastalıklarının maliyeti (2005-2014). Uluslararası Ekonomik Araștırmalar Dergisi, 3 (3), 479-489.

Davas, A., Türk, M. ve Yüksel, M. (2016). Çalışma koşulları ve iş kazaları arasındaki ilişkisi: Bir hastane örneği. Mesleki Sağllk ve Güvenlik Dergisi, 16(6061), 67-75.

Durgun, M., Serin, H. ve Şahin, Y. (2015). Palet üretim işçilerinin çalışma ortamı ve iş kazaları. Süleyman Demirel Üniversitesi Mühendislik Bilimleri ve Tasarm Dergisi, 3(3), 545-548.

Erginel, N., ve Toptanci, Ş. (2017). İş kazası verilerinin olasılık dağılımları ile modellenmesi. Mühendislik Bilimleri ve Tasarm Dergisi, 5, 201-212.

Eygü, H., Özçomak, S., ve Orçanlı, K. (2018). İşletmelerde meydana gelen iş kazalarının iş sağlığı ve güvenliği bakımından incelenmesi. 19. Uluslararası Ekonometri Yöneylem Araştırması ve İstatistik Sempozyumu, Tam Metin Bildiri Kitabı, Antalya, Turkey.

Eygü, H., ve Kılınç, A. (2019). Sosyo-ekonomik gelişmişlik algısı üzerinde etkili olan faktörlerin sıralı logit model yardımıyla araştırılması: ErzurumKayseri örneği. Journal of Academic Value Studies, 5 (5), 1023-1040.

ILO (2018). Statistics of occupational injuries, 28.01 .2019 tarihinde .http://www.ilo.org/wcmsp5/groups/public/dgreports/tat/documents/meetingdocument/wcms 088373.pdf adresinden erişilmiştir.

Kaplan, M. ve Çallı Kaplan, M. (2019). Türkiye'de çalışanların demografik özelliklerinin iş kazalarına etkilerinin analizi. Yönetim ve Ekonomi Araştırmaları Dergisi. 17 (2), 74-89. 
Nagelkerke, N. J. (1991). A note on a general definition of the coefficient of determination. Biometrika, 78(3), 691-692.

Oğuz, Ö. (2018). İş kazası ve meslek hastalığında sigortalıya sağlanan yardımlar. Emek ve Toplum Dergisi, 7 (18), 317-332.

Oktay, E., ve Orçanlı, K. (2014). Atatürk Üniversitesinde internet bankacilığının kullanımın etkileyen faktörlerin belirlenmesi. Uşak Üniversitesi Sosyal Bilimler Dergisi, 7(2), 57-91.

Özdamar, K. (1999). Paket programlar ile istatistiksel veri analizi (Cilt 1, 2.Baskl). Eskişehir: Kaan Kitabevi.

Özkan, H. (2016). İş kazalarından doğan ceza sorumluluğunda kusur tespiti. Gazi Üniversitesi Hukuk Fakültesi Dergisi. 20 (1), 511-571.

Polat, B. ve Polat, A. (2017). İnşaat sektöründe Doğu Anadolu Bölgesi için iş güvenliği koşullarının incelenmesi. IJPAS, 3(1), 24-32.

SGK (2016). 2016/21 sayılı Kısa Vadeli Sigorta Kolları Uygulamaları Genelgesi. Ankara.

SGK (2017). 2017 İstatistik Yilliğı. Ankara. 02.02.2020 tarihinde http://www.sgk.gov.tr/wps/portal/sgk/tr/kurumsal/istatistik/sgk istatistik yilliklari adresinden erişilmiştir.

Sümer, H.H. (2019). İş sağhlğı ve güvenliği hukuku (3. Baskı). Ankara: Seçkin Yayınevi.

TDK-Türk Dil Kurumu (2019). Güncel Türkçe sözlük. 31.01 .2020 tarihinde https://sozluk.gov.tr/ adresinden erişilmiştir.

Ulutaş, B. (2016). Türkiye'deki illerin iş kazaları ve meslek hastalıkları açısından veri zarflama analizi ile değerlendirilmesi. Cumhuriyet Üniversitesi İktisadi ve İdari Bilimler Dergisi, 17(2), 23-46.

Ünal, H. G., Arif, G. Ö. K., ve Kadir, G. Ö. K. Türkiye'de iş kazalarının il bazında analizi. Kastamonu Ĕ̆itim Dergisi, 17(1), 289-300.

\section{Kaynakça Bilgisi / Citation Information}

Bulut, M. ve Eygü, H. (2020). İş kazalarının lojistik regresyon yöntemi ile incelenmesi: Bayburt İli örneği. OPUS-Uluslararası Toplum Araştırmaları Dergisi, 15(10. Y1l Özel Sayıs1), 4956-4974. DOI: 10.26466/opus.684909 